\title{
SOFC Operation with Real Biogas
}

\author{
Hagen, Anke; Winiwarter, Anna; Langnickel, Hendrik; Johnson, Gregory
}

\section{Published in:}

Fuel Cells

Link to article, DOI:

10.1002/fuce.201700031

Publication date:

2017

Document Version

Peer reviewed version

Link back to DTU Orbit

Citation $(A P A)$ :

Hagen, A., Winiwarter, A., Langnickel, H., \& Johnson, G. (2017). SOFC Operation with Real Biogas. Fuel Cells, 17(6), 854-861. https://doi.org/10.1002/fuce.201700031

\section{General rights}

Copyright and moral rights for the publications made accessible in the public portal are retained by the authors and/or other copyright owners and it is a condition of accessing publications that users recognise and abide by the legal requirements associated with these rights.

- Users may download and print one copy of any publication from the public portal for the purpose of private study or research.

- You may not further distribute the material or use it for any profit-making activity or commercial gain

- You may freely distribute the URL identifying the publication in the public portal

If you believe that this document breaches copyright please contact us providing details, and we will remove access to the work immediately and investigate your claim 


\title{
SOFC Operation with Real Biogas
}

\author{
A. Hagen ${ }^{1 *}$, A. Winiwarter ${ }^{1}$, H. Langnickel ${ }^{1}$, G. Johnson ${ }^{1}$ \\ 1 DTU Energy, Frederiksborgvej 399, 4000 Roskilde, Denmark
}

Biogas is a valuable energy source and will be available in future in systems relying on renewables. It is an attractive fuel for solid oxide fuel cells (SOFC), which are able to utilize the carbon contained in the biogas and which produce electricity with high efficiency. In the current paper, state-of-the-art SOFCs were studied regarding performance and durability in relation to biogas as fuel and considering important contaminants, specifically sulfur. First, the catalytic behavior in relevant synthetic biogas mixtures was studied and the

\section{Introduction}

Biomass - in particular waste biomass - is one of the largest sources for energy production in future systems not relying on fossil fuels. From a variety of potential biomass conversion routes, production of biogas - a mixture of mainly methane and $\mathrm{CO}_{2}$ - through anaerobic digestion is a widely applied technology throughout the world. For example, in 20145.5 PJ biogas were produced in Denmark [1]. For comparison, in the same year, $47 \mathrm{PJ}$ electricity were produced from wind, which accounted for $41 \%$ of the total electricity production in Denmark [2]. Thus the energy potential of biogas is significant and the production is increasing steeply. Biomass sources comprise domestic and industry waste-water or solid waste from disposal sites. Furthermore, many developing countries, for example India and China, have biogas units using domestic waste for cooking or heating purposes, often in rural areas. Considering biomass in total, a potential deployment level for energy could be in the range of 100 to $300 \mathrm{EJ}$ by 2050 [3]. While traditional combustion units for biogas run at low efficiencies and can only use biogas with sufficient methane content, solid oxide fuel cells (SOFC) can provide high electrical efficiencies of $40-60 \%$ and even higher when combined with the heat usage. Furthermore, they can be operated in the desired power range of several $\mathrm{kW}$. The large potential of using biogas for combined heat and power production was for example analyzed by Torija et al. [4] and Van herle et al. [5]. Particular advantages of the SOFC technology are high electrical efficiency already at small power ranges $\left(5-20 \mathrm{~kW}_{\mathrm{el}}\right)$, operation even at very small methane content, silent and safe operation, expected low maintenance costs and low emissions (NOx, SOx). potential of dry reforming was demonstrated. Successful long term operation of an SOFC under both, conditions of steam and dry reforming, i.e., addition of steam or $\mathrm{CO}_{2}$ to avoid carbon formation was shown. For the steam reforming case a remarkable period of 3,500 h, hereof 3,000 $\mathrm{h}$ in the presence of $\mathrm{H}_{2} \mathrm{~S}$ was achieved. Finally, a real biogas from a landfill gas unit was used as fuel. The concept of dry reforming was realized. The SOFC was successfully operated with and in one case even without a specific gas cleaning unit.

Keywords: Biogas, Durability, Reforming, SOFC, Sulfur

Biogas consists mainly of methane $\left(\mathrm{CH}_{4}, 50-80 \mathrm{vol} \%\right.$ ) and $\mathrm{CO}_{2}$ (30-50 vol.\%). The main constituents open a number of options to form $\mathrm{H}_{2}$ and $\mathrm{CO}$ that can be used as fuel in SOFC: dry reforming, steam reforming, and partial oxidation (Eqs. (1) to (3)). These reactions can proceed within state-ofthe-art SOFC anodes that contain nickel as catalyst. With those reactants, also water gas shift reaction and carbon deposition reactions can occur.

$\mathrm{CH}_{4}+\mathrm{CO}_{2} \Leftrightarrow 2 \mathrm{CO}+2 \mathrm{H}_{2}$

$\mathrm{CH}_{4}+\mathrm{H}_{2} \mathrm{O} \Leftrightarrow \mathrm{CO}+3 \mathrm{H}_{2}$

$\mathrm{CH}_{4}+\frac{1}{2} \mathrm{O}_{2} \Leftrightarrow \mathrm{CO}+2 \mathrm{H}_{2}$

Depending on the biomass source, the specific composition and presence of minor compounds and impurities vary significantly. Without aiming at giving a full analysis of biogas, Table 1 illustrates the large possible ranges of contaminants (from [6]). In addition to the listed compounds, also siloxanes were found in biogas (0-50 $\mathrm{mg} \mathrm{Nm}^{-3}$, [7]). While nitrogen or ammonia are not critical for SOFCs - nitrogen is an inert gas and ammonia is cracked under SOFC operation and using state-of-the-art cells and the formed hydrogen acts as fuel other contaminants can have detrimental effects on the SOFC

[*] Correspondingauthor, anke@dtu.dk 
performance. As the other compounds vary both in nature and content, a certain degree of cleaning is needed.

Among the impurities, sulfur compounds have attracted most attention. They are even more critical, when carbon containing fuel is used compared to a fairly high tolerance of SOFC in hydrogen fuel (e.g., [8-13]). The catalytic sites in the SOFC anode that are responsible for the internal reforming reaction (reaction (2)) are more affected by the presence of sulfur impurities than the actual electrochemical oxidation. Only a few groups have studied the poisoning effects of other relevant impurities such as boron, chlorine and phosphorous containing compounds [14].

The Ni/YSZ type SOFC anodes catalyse the internal reforming of methane for example in biogas, which is the focus of this paper. Although biogas has been identified as promising sustainable fuel for SOFC, most studies have concentrated on studies using simulated biogas mixtures. Staniforth and Kendall $[15,16]$ for example investigated different biogas compositions on small tubular SOFCs. Carbon deposition and sulfur poisoning were identified as main degradation sources. Initial tests with real biogas were run over short periods of ca. $60 \mathrm{~min}$. Guerra et al. [17] mixed a simulated biogas with additional $\mathrm{CO}_{2}$ in order to enable dry reforming (reaction (1)) and avoiding carbon deposition on a tubular SOFC. The more $\mathrm{CO}_{2}$ was added the more the fuel was diluted with consequently reaching a lower initial performance of the SOFC. Durability tests over few hundred hours were carried out by Lanzini et al. [18] on state-of-the-art planar SOFC and a beneficial effect of adding more $\mathrm{CO}_{2}$ in the $\mathrm{CH}_{4}-\mathrm{CO}_{2}$ fuel mixture in regard to less carbon formation and thus less degradation was concluded. Not only for carbon formation, also for sulfur poisoning, the addition of $\mathrm{CO}_{2}$ seems to be beneficial. Initial catalytic studies on state-of-the-art anodes regarding poisoning by sulfur indicated that the presence of $\mathrm{CO}_{2}$ can mitigate the poisoning effect on the methane reforming reaction [19]. Progressing from these studies it is interesting, how impurities affect both, the electrochemical performance and the durability over thousands of hours, here particularly sulfur but also the whole mix of impurities that might be found in real biogas.

The current work evaluates the effect of sulfur on the catalytic properties of anodes in full SOFC for steam and dry reforming of biogas. Further, the electrochemical performance and durability of using biogas directly in a planar SOFC through a steam reforming or dry reforming concept was investigated. Tests with different mixtures of synthetic biogas were carried out with the aim to identify optimum fuel compositions regarding reforming concept, avoidance of carbon deposition, etc. Such tests also included addition of sulfur impurities. Finally, a real biogas collected from a landfill unit was tested directly under dry reforming conditions.

\section{Experimental}

The SOFC tests were performed on state-of-the-art SOFC, manufactured at DTU Energy. They were composed of a $\mathrm{Ni} / \mathrm{YSZ}$ anode support, a Ni/YSZ or Ni/ScYSZ anode, and a YSZ or ScYSZ electrolyte fabricated by tape casting and sintered together. A CGO barrier layer was deposited by PVD to avoid interaction between electrolyte and the screen printed LSC/CGO cathode. The cells were provided with a LSC or LSM cathode current collection layer.

For performance tests, the SOFCs were mounted in an alumina test housing by sandwiching them between Ni current collector and Ni mesh at the anode side and $\mathrm{Au}$ mesh at the cathode side. The active cell area was $16 \mathrm{~cm}^{2}$. The anode compartment was sealed using gold seals. The cathode part was not sealed (see sketch in Figure 1).

The mounted cell was placed in a test rig containing a furnace and the relevant gas supply and electronics. The test was initiated by heating to $850^{\circ} \mathrm{C}$ with a heating rate of $1^{\circ} \mathrm{C} \mathrm{min} \mathrm{m}^{-1}$ under Ar at the anode side. After sealing at this temperature for $2 \mathrm{~h}$, the anode gas was switched to $9 \mathrm{vol} \% \mathrm{H}_{2}$ in $\mathrm{N}_{2}$ to start anode reduction. After another $2 \mathrm{~h}$ the gas was switched to 20 $\mathrm{L} \mathrm{h}^{-1} \mathrm{H}_{2}$ containing 2.5 vol. $\% \mathrm{H}_{2} \mathrm{O}$ for $1 \mathrm{~h}$, followed by $25 \mathrm{~L} \mathrm{~h}^{-1}$

Table 1 Chemical composition of biogas from different waste sources [6].

\begin{tabular}{lllll} 
Components & Household waste & Wastewater treatment plants sludge & Agricultural wastes & Waste of agrifood industry \\
\hline $\mathrm{CH}_{4} /$ vol. $\%$ & $50-60$ & $60-75$ & $60-75$ & 68 \\
$\mathrm{CO}_{2} /$ vol.\% & $38-34$ & $33-19$ & $33-19$ & 26 \\
$\mathrm{~N}_{2} /$ vol.\% & $5-0$ & $1-0$ & $1-0$ & - \\
$\mathrm{O}_{2} /$ vol. $\%$ & $1-0$ & $<0,5$ & $<0,5$ & - \\
$\mathrm{H}_{2} \mathrm{O} / \mathrm{vol} . \%$ & $6\left(\right.$ at $\left.40^{\circ} \mathrm{C}\right)$ & $6\left(\right.$ at $\left.40^{\circ} \mathrm{C}\right)$ & $6\left(\right.$ at $\left.40^{\circ} \mathrm{C}\right)$ & $6\left(\right.$ at $\left.40^{\circ} \mathrm{C}\right)$ \\
$\mathrm{H}_{2} \mathrm{~S} / \mathrm{mg} \mathrm{m}^{-3}$ & $100-900$ & $1,000-4,000$ & $3,000-10,000$ & 400 \\
$\mathrm{ppm}^{*}$ & $70-600$ & $670-2,660$ & $2,000-6,660$ & 270 \\
$\mathrm{NH}_{3} / \mathrm{mg} \mathrm{m}^{-3}$ & - & - & $50-100$ & - \\
Aromatic / mg m & -3 & - & - & - \\
Organochlorinated or organofluorated / & $100-800$ & - & - & -
\end{tabular}

*Added by the authors. 


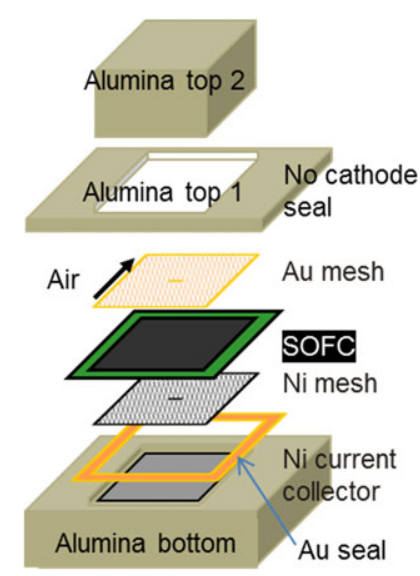

Fig. 1 Illustration of the test housing. Air and fuel gasses are operated in cross flow geometry.

dry $\mathrm{H}_{2}$ for another hour. The cathode gas flow (air) was slowly increased to $140 \mathrm{~L} \mathrm{~h}^{-1}$ at the same time. After sealing and reduction, an initial cell characterization (fingerprint) was carried out. It consisted of a standardised set of gas- and temperature variations to check the tightness and contacting of the setup and the performance of the cell by recording $I-V$ curves and impedance spectra. Afterwards, the desired operating conditions were adjusted, e.g., temperature $\left(750\right.$ or $\left.850^{\circ} \mathrm{C}\right)$ and gas flows and the test started. After each test segment the fingerprint procedure was repeated to compare cell performance before and after. In addition, electrical impedance spectra were recorded regularly during operation.

For synthetic gas mixtures, pure gasses were fuelled from bottles through mass flow controllers. The real biogas was collected directly from the landfill location, compressed to approximately 3.0-3.5 bar, dried to a dew point of $3{ }^{\circ} \mathrm{C}$ by condensation, and filled into $50 \mathrm{~L}$ gas cylinders. Afterwards, approximately 0.75 bar pure $\mathrm{CO}_{2}$ were added directly into the bottles yielding a gas composition of ca. 45 vol. $\% \mathrm{CO}_{2}$, 32 vol. $\% \mathrm{CH}_{4}, 23$ vol. $\% \mathrm{~N}_{2}$.

When real biogas was used, the fuel was for some of the test segments led through a gas cleaning filter with $10 \mathrm{~g}$ activated carbon pellets (Norit ROZ 3, Cabot, USA) at room temperature before entering the cell.

\section{Results and Discussion}

\subsection{Catalytic Activity of Anodes in Full Cells}

Before evaluating the electrochemical performance in the relevant biogas fuel mixtures, the catalytic properties of typical state-of-the-art (SoA) anodes were studied in full cells, i.e., in the environment and the specific structure as also present during SOFC operation. Such studies represent a progress from previous catalytic studies on anodes alone (for example by Johnson et al. [19]) towards real SOFCs. The aim was to evaluate the poisoning effect of sulfur as most prominent representative for contaminants entirely on the catalytic (and not yet electrochemical) reactions in gas mixtures representing dry or steam reforming of biogas. Therefore, the SOFC cell testing setup was used under open circuit voltage (OCV) conditions, i.e., under purely catalytic conditions, without polarization.

Successively, the involved gasses were fuelled to the SOFC at OCV and the degree of sulfur poisoning determined by adding defined amounts of $\mathrm{H}_{2} \mathrm{~S}$ in the ppm range at $850^{\circ} \mathrm{C}$. In Figure 2, the observed OCVs are shown for all gas mixtures and different $\mathrm{H}_{2} \mathrm{~S}$ concentrations. The OCV is determined by the gas composition (Nernst equation) and a change of its value is directly related to the change of the gas composition. When sulfur is added, the catalytic processes are affected and the gas composition deviates from equilibrium, i.e., sulfur leads to a decrease of the respective gas conversion. In other words, with increasing the sulfur content, more inlet fuel passes unconverted through the SOFC, which in turn leads to a decrease of the OCV. Theses OCV values can be directly translated to a fuel composition and fuel conversion through the Nernst equation, using an in-house calculation routine (see also [10]). In Figure 3 these gas conversion values as function of sulfur content calculated from the OCV values in Figure 2 are shown.

The test segment done with hydrogen, entirely, is shown Figure 2, red curves. As there are no catalytic reactions at $\mathrm{OCV}$, no effect of sulfur was expected. Indeed, the cell voltage is constant for all added sulfur amounts, which were dosed by substituting the corresponding amount of hydrogen by $\mathrm{H}_{2} \mathrm{~S}$ in hydrogen. Moreover, the measured OCV of $913 \mathrm{mV}$ is only $5 \mathrm{mV}$ less than the theoretical expected value, indicating a tight setup.

The next segment was directed towards the water gas shift reaction and therefore, $\mathrm{CO}$ was added to the fuel (Figure 2, orange curves and Figure 3a). The cell voltage in the absence of sulfur was around $907 \mathrm{mV}$ and thus only ca. $9 \mathrm{mV}$ from the

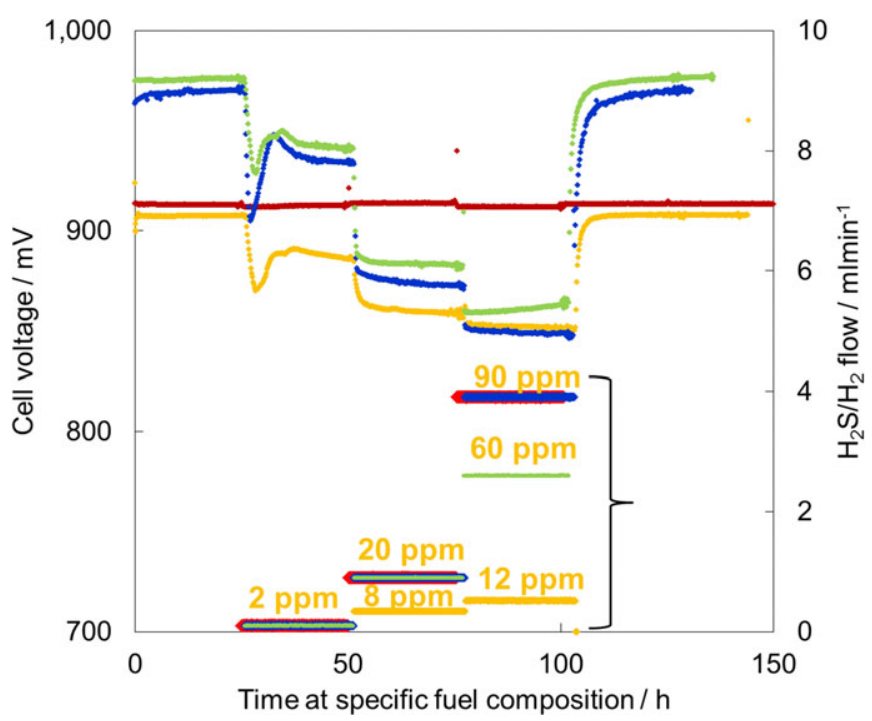

Fig. $2 \mathrm{OCV}$ in different fuel mixtures with/without $\mathrm{H}_{2} \mathrm{~S}$ at $850^{\circ} \mathrm{C}$ (left axis) $\mathrm{H}_{2} \mathrm{~S}$ concentrations (right axis). Red: $47 \% \mathrm{H}_{2}, 53 \% \mathrm{H}_{2} \mathrm{O}$; Orange: $42 \%$ $\mathrm{CO}, 5 \% \mathrm{H}_{2}, 53 \% \mathrm{H}_{2} \mathrm{O}$; Blue: $29 \% \mathrm{CH}_{4}, 13 \% \mathrm{H}_{2}, 58 \% \mathrm{H}_{2} \mathrm{O}$; Green: $50 \%$ biogas $\left(30 \% \mathrm{CH}_{4}+20 \% \mathrm{CO}_{2}\right), 10 \% \mathrm{H}_{2}, 40 \% \mathrm{H}_{2} \mathrm{O}$, all vol. $\%$. 

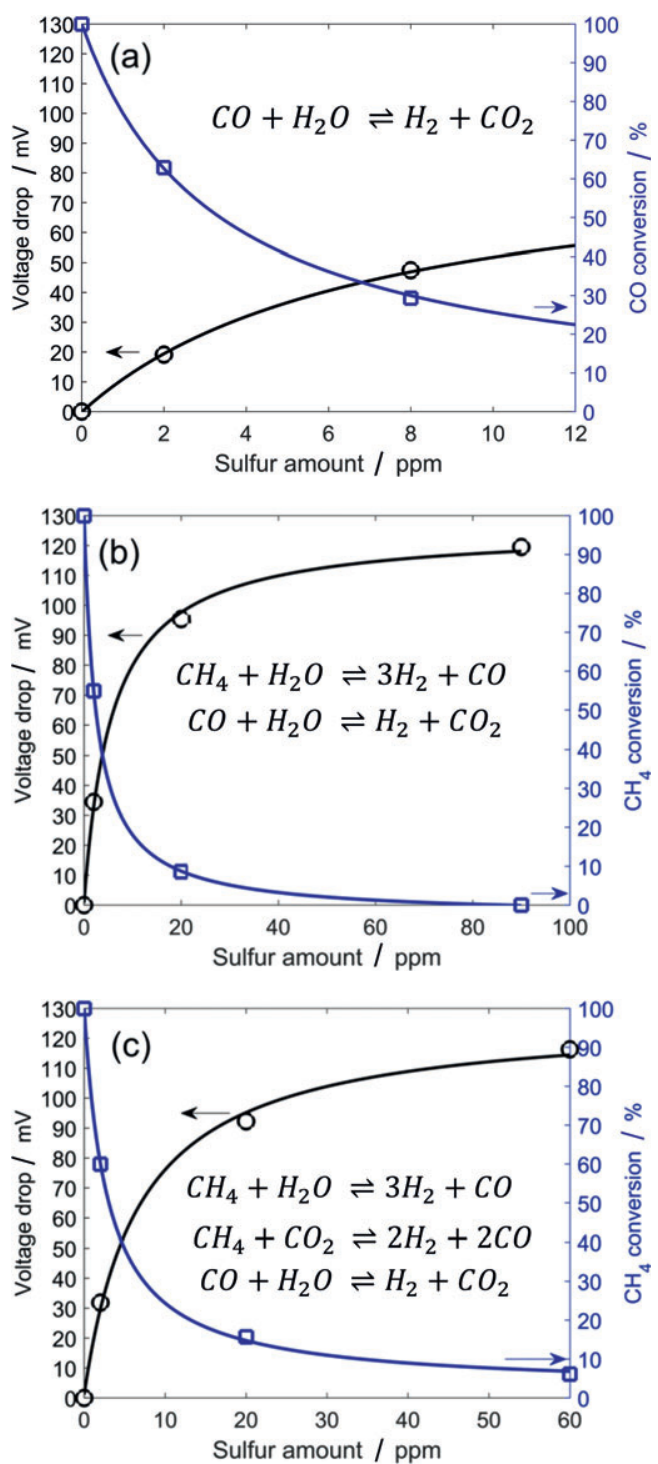

Fig. 3 OCV drop and corresponding change of conversion vs. sulfur content (a) $42 \% \mathrm{CO}, 5 \% \mathrm{H}_{2}, 53 \% \mathrm{H}_{2} \mathrm{O}$ (WGS reaction); (b) $29 \% \mathrm{CH}_{4}$, $13 \% \mathrm{H}_{2}, 58 \% \mathrm{H}_{2} \mathrm{O}$ (methane steam reforming and WGS reaction); (c) $50 \%$ biogas $\left(30 \% \mathrm{CH}_{4}+20 \% \mathrm{CO}_{2}\right), 10 \% \mathrm{H}_{2}, 40 \% \mathrm{H}_{2} \mathrm{O}$ (methane dry and steam reforming and WGS reaction), all vol.\%.

theoretical value. Adding $2 \mathrm{ppm}$ of $\mathrm{H}_{2} \mathrm{~S}$, the cell voltage dropped to around $888 \mathrm{mV}$, after some initial period of adjustment (the origin of which is not known, currently; it might be due to gas mixing issues at the fuel inlet). The cell voltage dropped further when the $\mathrm{H}_{2} \mathrm{~S}$ concentration was successively increased to 8 and $12 \mathrm{ppm}$. After stopping the addition of $\mathrm{H}_{2} \mathrm{~S}$, the cell voltage returned to the initial value indicating a reversible poisoning (Figure 2, orange curve). When the OCV is translated into a conversion of $\mathrm{CO}$, a decrease from ca. 100 to $23 \%$ is observed when increasing the sulfur concentration from 0 to $12 \mathrm{ppm}$ (Figure 3a). The conclusion from this test segment is that the water gas shift reaction is poisoned significantly but in a reversible manner by sulfur in the applied concentrations. The critical sulfur concentrations causing an effect are in the range of $1-10 \mathrm{ppm} \mathrm{H}_{2} \mathrm{~S}$.
The next test was performed in a steam reforming environment, i.e., methane and steam were the main fuel gasses. The initial OCV value of $970 \mathrm{mV}$ deviated only by $25 \mathrm{mV}$ from the theoretical value. When $\mathrm{H}_{2} \mathrm{~S}$ was added, the OCV dropped successively with increasing concentration (Figure 2, blue curves). The magnitude of the $\mathrm{OCV}$ drop with $2 \mathrm{ppm}_{2} \mathrm{~S}$ was larger as compared to $\mathrm{CO}$ in the fuel. However, a better comparison of the catalytic activities is possible from the methane conversion rates as shown in Figure $3 \mathrm{~b}$. The conversion dropped from ca. $100 \%$ in the absence of sulfur, to a few $\%$ in the presence of $90 \mathrm{ppm}$. While this poisoning is severe, it is also amazing, that such high $\mathrm{H}_{2} \mathrm{~S}$ concentrations still allow for any methane conversion at all.

The last test segment was focused on introducing dry reforming to a certain degree, i.e., steam in the fuel was partly substituted by $\mathrm{CO}_{2}$. The measured $\mathrm{OCV}$ of $975 \mathrm{mV}$ is again very close to the theoretic one (difference ca. $14 \mathrm{mV}$ ). With the addition of sulfur, the OCV dropped illustrating a poisoning effect (Figure 2, green curves). By using ca. $60 \mathrm{ppm} \mathrm{H}_{2} \mathrm{~S}$ in this test segment for dry reforming as maximum sulfur content, the methane conversion was a few $\%$ and thus equally small as for the steam reforming conditions. However, in the smaller concentration ranges, $\sim 20 \mathrm{ppm} \mathrm{H}_{2} \mathrm{~S}$ (Figure 3c), a difference was observed. Here, the methane conversion was larger in the dry reforming concept, which seems to be in line with the results of the dry reforming SOFC anode tests by Johnson et al. [19] where a better sulfur tolerance under dry conditions was found. Thus, dryer conditions seem more attractive in combination with methane reforming and under the risk of sulfur poisoning. The relevant $\mathrm{H}_{2} \mathrm{~S}$ concentrations to induce a poisoning effect were identified in the range of a few to tens ppm.

\subsection{Synthetic Biogas - Steam Reforming}

Following these catalytic studies, electrochemical tests of SOFC in relevant gas mixtures were carried out to evaluate how well SoA cells behave under biogas/reforming conditions without and with the presence of sulfur.

In previous studies, steam reforming with $\mathrm{CH}_{4}$ was studied, including the effect of $\mathrm{H}_{2} \mathrm{~S}$ impurities [8]. It was found that ca. 2 ppm $\mathrm{H}_{2} \mathrm{~S}$ can be tolerated although both, the reforming of methane and the electrochemical reactions were poisoned. The reversibility of degradation depended on the used anode and operating conditions. In the current work, steam was added to a synthetically mixed biogas. The difference to the previous studies was thus the presence of $\mathrm{CO}_{2}$ in the initial fuel feed. In Figure 4, the power output of the single cell and the area specific serial and polarization resistances deduced from impedance spectroscopy under current load (i.e. during operation) are shown. The values of the degradation rates are listed in Table 2. In the first $500 \mathrm{~h}$ operation in synthetic biogas and steam, the power output decreased with a rate of ca. $26 \mathrm{~mW} \mathrm{~cm}^{-2} 1,000 \mathrm{~h}^{-1}$ (Table 2). That is a significant value. The origin of this degradation is due to both, an increase of the serial as well as polarization resistance. A more detailed eva- 
Table 2 Degradation rates of the cell power output and the serial and polarization resistances for the tests in syn biogas mixed with steam (see Figure 4, Figure 5, Figure 7).

\begin{tabular}{|c|c|c|}
\hline Degradation rate & $\mathrm{No} \mathrm{H}_{2} \mathrm{~S}$ & With $\mathrm{H}_{2} \mathrm{~S}$ \\
\hline \multicolumn{3}{|l|}{ Steam reforming $750^{\circ} \mathrm{C}$} \\
\hline 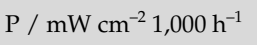 & 26 & 29 \\
\hline Rs / $\mathrm{m} \Omega \mathrm{cm}^{2} 1,000 \mathrm{~h}^{-1}$ & 5 & 63 \\
\hline $\mathrm{Rp} / \mathrm{m} \Omega \mathrm{cm}^{2} 1,000 \mathrm{~h}^{-1}$ & 42 & 40 \\
\hline \multicolumn{3}{|l|}{ Steam reforming $850^{\circ} \mathrm{C}$} \\
\hline $\mathrm{P} / \mathrm{mW} \mathrm{cm}^{-2} 1,000 \mathrm{~h}^{-1}$ & & 20 \\
\hline Rs / $\mathrm{m} \Omega \mathrm{cm}^{2} 1,000 \mathrm{~h}^{-1}$ & & 1 \\
\hline $\mathrm{Rp} / \mathrm{m} \Omega \mathrm{cm}^{2} 1,000 \mathrm{~h}^{-1}$ & & 60 \\
\hline \multicolumn{3}{|l|}{ Dry reforming $850^{\circ} \mathrm{C}$} \\
\hline 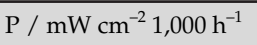 & & -20 \\
\hline $\mathrm{Rs} / \mathrm{m} \Omega \mathrm{cm}^{2} 1,000 \mathrm{~h}^{-1}$ & & -10 \\
\hline $\mathrm{Rp} / \mathrm{m} \Omega \mathrm{cm}^{2} 1,000 \mathrm{~h}^{-1}$ & & -40 \\
\hline
\end{tabular}

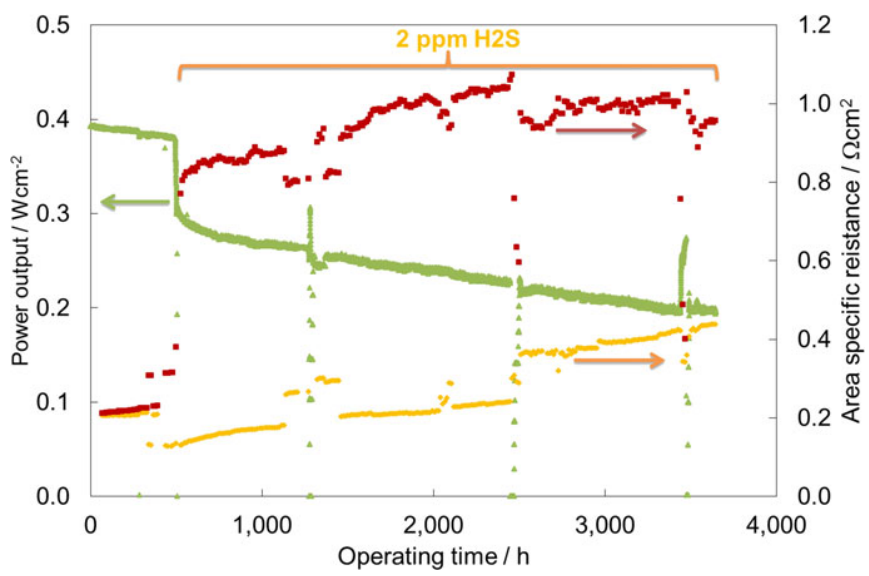

Fig. 4 Power output (left axis) and area specific resistances (right axis: yellow: serial resistance, red: polarization resistance) during durability test in $30 \% \mathrm{CH}_{4}, 15 \% \mathrm{CO}_{2}, 60 \% \mathrm{H}_{2} \mathrm{O}$ (all vol.\%) with and without $2 \mathrm{ppm} \mathrm{H}_{2} \mathrm{~S}$ at $750^{\circ} \mathrm{C}, 0.5 \mathrm{~A} \mathrm{~cm}^{-2}$.

luation of the polarization resistance in the impedance data reveals that the main increase is in the contribution around a frequency of $1,000 \mathrm{~Hz}$ and thus related to anode processes [20]. Such a degradation of SoA type cells under steam reforming conditions - though without addition of $\mathrm{CO}_{2}$ as in this study - might be due to carbon deposition.

When $\mathrm{H}_{2} \mathrm{~S}$ was added to the fuel, the power output dropped significantly. At the same time, the polarization resistance increased. Both observations are in line with literature results and are related to the adsorption of $\mathrm{H}_{2} \mathrm{~S}$ at active sites in the SoA anode $([9,10])$. In the subsequent period of $3,000 \mathrm{~h}$, the SOFC was run in the presence of 2 ppm $\mathrm{H}_{2} \mathrm{~S}$ in the synthetic biogas-steam fuel. Such a long durability test under similar reforming and $\mathrm{H}_{2} \mathrm{~S}$ addition was not yet reported previously. The power output continued to decrease and also the serial and polarization resistances continued to increase as well. There are some discontinuities in Figure 4 which are due to gas supply problems. Interestingly, the power output degradation rate in the presence of $\mathrm{H}_{2} \mathrm{~S}$ was only slightly increased compared to the operation without sulfur, ca. $29 \mathrm{~mW} \mathrm{~cm}^{-2} 1,000 \mathrm{~h}^{-1}$ (see Table 2). Due to the discontinuities in the gas supply, it is difficult to precisely determine the resistance degradation rates during test in the presence of $\mathrm{H}_{2} \mathrm{~S}$. However, the trends are obvious. While the polarization resistance increased with a similar rate both with and without $\mathrm{H}_{2} \mathrm{~S}$, the serial resistance increased significantly more during $\mathrm{H}_{2} \mathrm{~S}$ addition (see values in Table 2). Such trends were observed in steam reforming long term tests in the presence of $\mathrm{H}_{2} \mathrm{~S}$ where they were related to a loss of $\mathrm{Ni}$ particle percolation close to the anode/electrolyte interface [9]. It is very probable that similar processes occur in the present study. Even though the performance after more than 3,500 $\mathrm{h}$ of testing and here 3,000 $\mathrm{h}$ with $\mathrm{H}_{2} \mathrm{~S}$ still was remarkable, the observed degradation trends, in particular the increase of the serial resistance lead to the conclusion that an operation with such high sulfur content and applied fuel containing synthetic biogas and steam will not be feasible for realistic expected life times.

It is well known that the poisoning effect of sulfur decreases with increasing temperature, because the sulfur coverage of the nickel in the SOFC anode decreases [21]. This has in turn consequences for the reforming of methane. The reaction rate for steam reforming on $\mathrm{Ni}$ based catalysts is retarded with the third power in relation to the sulfur coverage $\left(1-\theta_{S}\right)^{3}$ [22].

Another durability test was therefore run at a higher operating temperature of $850^{\circ} \mathrm{C}$ (see Figure 5). Although this test was run at a shorter time period, it is obvious that the degradation rates were in the similar range under $\mathrm{H}_{2} \mathrm{~S}$ exposure, even though the higher temperature was expected to allow for a better durability. Only the serial resistance (see Table 2) did not increase as fast and therefore, a longer lifetime can be expected for the test at higher operating temperature.

As a conclusion from these tests and considering the use of biogas and the steam reforming, a higher dilution with steam and/or even lower concentration of $\mathrm{H}_{2} \mathrm{~S}$, i.e., a better cleaning of the gas, is recommended.

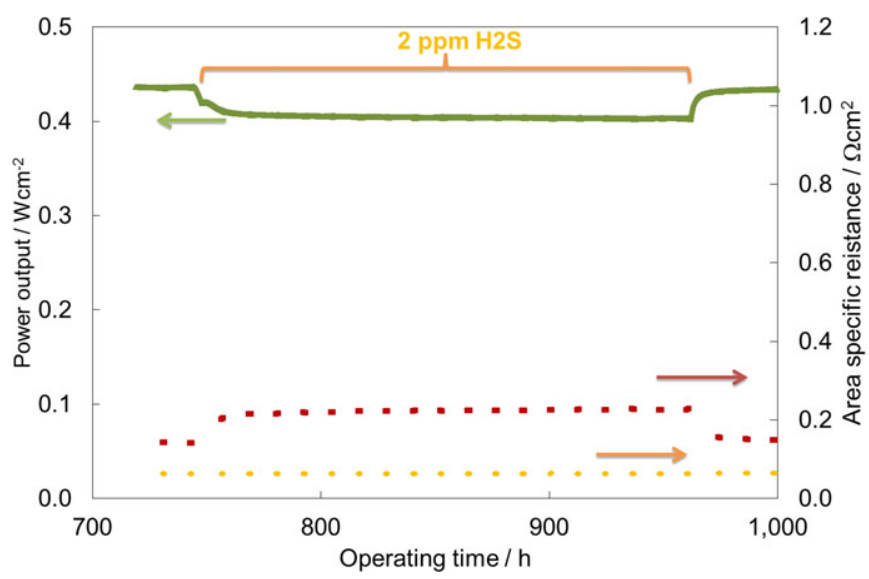

Fig. 5 Power output and serial and polarization resistance in $50 \%$ biogas $\left(30 \% \mathrm{CH}_{4}+20 \% \mathrm{CO}_{2}\right.$ ), $10 \% \mathrm{H}_{2}, 40 \% \mathrm{H}_{2} \mathrm{O}$ (all vol. $\%$ ) with and without $2 \mathrm{ppm} \mathrm{H}_{2} \mathrm{~S}$ at $850^{\circ} \mathrm{C}, 0.5 \mathrm{~A} \mathrm{~cm}^{-2}$. 


\subsection{Dry Reforming}

The dry reforming is another option for the direct use of biogas as fuel for SOFCs. As pointed out earlier, the poisoning effect of $\mathrm{H}_{2} \mathrm{~S}$ was in fact smaller in $\mathrm{CO}_{2}$ containing atmosphere as compared to steam in comparative catalytic studies on anode materials [19]. It was therefore interesting to test, if this behavior is also valid on the full cell under operating conditions.

\subsubsection{Carbon Formation}

As already stated in the introduction, biogas inherently contains a reforming agent, i.e., $\mathrm{CO}_{2}$. When aiming at the dry reforming concept, it is important to identify the carbon deposition ranges. In order to guide the choice of fuel gas composition, thermodynamic calculations of the carbon formation at different realistic temperatures were carried out using the commercial software FactSage. Figure 6 shows the obtained ternary phase diagram of the system $\mathrm{C}-\mathrm{O}-\mathrm{H}$ at selected temperatures. At all temperatures above $100^{\circ} \mathrm{C}$, two regions can be separated: A region in which solid carbon is stable, and a region in which only gasses are present in equilibrium. The size of the carbon deposition window decreases with increasing temperature, as expected.

The typical expected biogas composition of 60 vol. $\% \mathrm{CH}_{4}$ and 40 vol. $\% \mathrm{CO}_{2}$ for the landfill source is shown in Figure 6 as hollow circle. Even at the highest temperature of $850^{\circ} \mathrm{C}$, this mixture is in the carbon deposition region. Therefore, it is clear, that addition of oxygen donating species is necessary to prevent carbon formation at the anode, as also pointed out by Guerra et al. [17]. The two other hollow markers represent the trend when going to higher concentrations of $\mathrm{CH}_{4}$ (square) and to the opposite, i.e., highly diluted biogas (triangle). More realistic compositions are represented by full markers. They were used in the current study of biogas dry reforming and of real biogas from a landfill unit. Even though the calculations

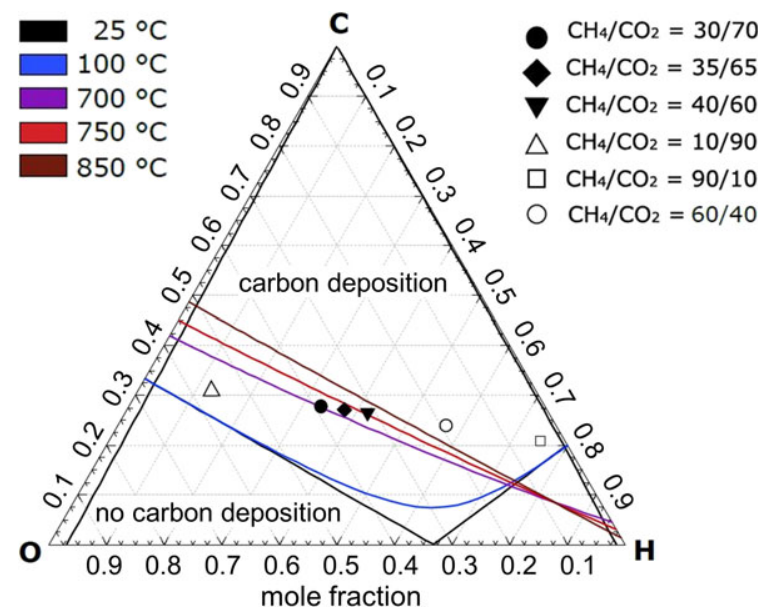

Fig. 6 Ternary phase diagram of the system $\mathrm{C}-\mathrm{H}-\mathrm{O}$ at $1 \mathrm{~atm}$ and selected temperatures from $25^{\circ} \mathrm{C}$ to $850^{\circ} \mathrm{C}$. The positions of mixtures of $\mathrm{CH}_{4}$ and $\mathrm{CO}_{2}$ in different ratios are shown. Full markers refer to compositions later used in the tests. The hollow circle shows the composition expected for real landfill biogas. The other two hollow markers show extrema. show that these compositions are outside the carbon formation range at the desired SOFC operating temperature, a carbon formation cannot be completely excluded for example due to local thermal gradients.

\subsubsection{Durability under Dry Reforming in Synthetic Biogas}

A durability test was carried out under similar conditions as in the previous section, only with addition of extra $\mathrm{CO}_{2}$ instead of steam. The results are shown in Figure 7 and Table 2. In fact, the observed SOFC long term performance confirms the better tolerance towards $\mathrm{H}_{2} \mathrm{~S}$ in the presence of excess $\mathrm{CO}_{2}$ in a biogas fuel. Even an activation of performance was observed over the 200 hours in the presence of $\mathrm{H}_{2} \mathrm{~S}$.

These promising results were used to design a SOFC test using real biogas under dry reforming conditions.

\subsection{Performance and Durability under Dry Reforming and Real Biogas}

In order to obtain a base line, the test was started in synthetically mixed biogas with the expected composition, i.e., including inert gas. In Table 3, the gas compositions and OCV values are shown for the pre-mixed and real biogas. For the

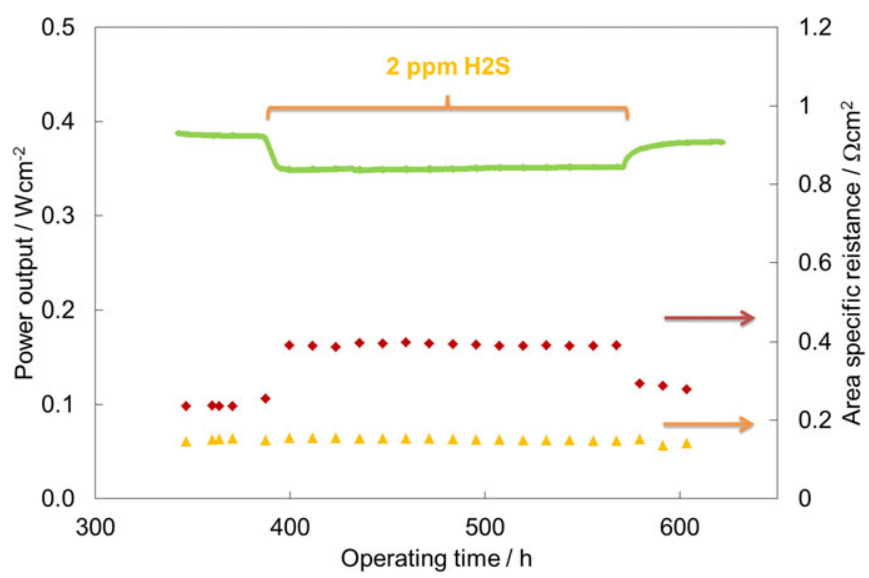

Fig. 7 Power output and serial and polarization resistance in biogas with additional $\mathrm{CO}_{2}, 50 \%$ biogas $\left(30 \% \mathrm{CH}_{4}+20 \% \mathrm{CO}_{2}\right), 20 \% \mathrm{H}_{2}$, $30 \% \mathrm{CO}_{2}$ (all vol.\%) with and without $2 \mathrm{ppm} \mathrm{H}_{2} \mathrm{~S}$ at $850^{\circ} \mathrm{C}, 0.5 \mathrm{~A} \mathrm{~cm}^{-2}$.

Table 3 OCV values for synthetic biogas and landfill gas.

\begin{tabular}{lll} 
& Syn biogas & Landfill gas \\
\hline Gas composition / vol.\% & \\
$\mathrm{CH}_{4}$ & 28 & 32 \\
$\mathrm{CO}_{2}$ & 42 & 44 \\
$\mathrm{Ar} / \mathrm{N}_{2}{ }^{*}$ & 30 & 23.2 \\
$\mathrm{O}_{2}$ & 0 & 0.8 \\
$\mathrm{OCV} / \mathrm{mV}$ & & \\
Theoretical & 1,048 & 1,053 \\
Measured & 1,040 & 1,051
\end{tabular}

* The fuel for the syn biogas contained Ar due to availability in the test rig, while the landfill gas contained $\mathrm{N}_{2}$. 
first parts of the test with real biogas, the landfill gas was cleaned using an active carbon filter.

As already mentioned, the OCV values reflect both the setup conditions and gas composition. The closer the measured value to the theoretic one as calculated using the Nernst equation, the better the testing setup. In the current test, the difference was always less than $10 \mathrm{mV}$ indicating a tight setup.

Figure 8 shows a comparison between the $I-V$ curves recorded in synthetic biogas and landfill gas. In order to avoid effects of degradation, they were recorded immediately after each other. Both curves coincide very well. The starvation at higher current densities is a consequence of the fuel composition and high fuel utilization. The fuel utilization corrected area specific resistances were 0.22 and $0.23 \Omega \mathrm{cm}^{2}$ in synthetic biogas and landfill, respectively. These values indicate a good comparability between the premixed and the real biogas after cleaning in an active carbon filter.

Figure 9 shows the results of constant operation using both landfill and synthetic biogas. In the ca. 420 hours before feeding the landfill gas, the cell was run in synthetic biogas both at constant current and at OCV (not shown in the figure). The

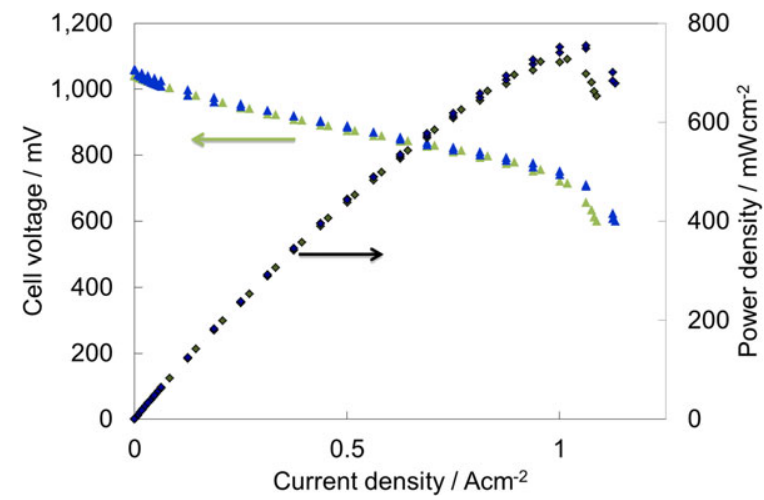

Fig. $8 I-V$ curves recorded immediately after each other in synthetic biogas (green) and landfill gas with added $\mathrm{CO}_{2}, 1$ st bottle (blue), $750^{\circ} \mathrm{C}$, for fuel composition see Table 3.

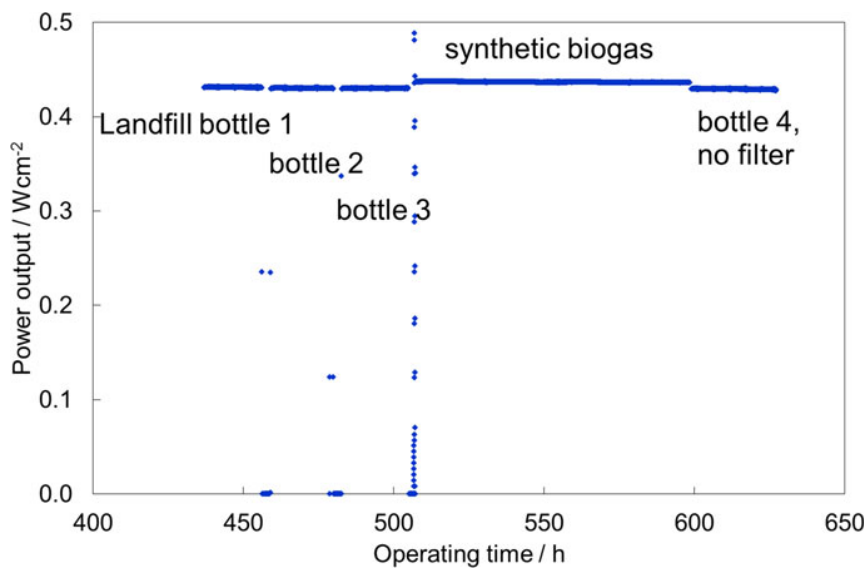

Fig. 9 Power output during long term test using four bottles of landfill gas with added $\mathrm{CO}_{2}$ and a period with synthetic biogas before and in between, $750^{\circ} \mathrm{C}, 0.5 \mathrm{~A} \mathrm{~cm}^{-2}$. first three bottles with landfill gas and added $\mathrm{CO}_{2}$ including gas cleaning show the expected power output and a very low degradation rate (see Figure 9). After switching to a synthetically mixed biogas, there was almost no change of performance, again showing a very good stability. During the last segment the fourth landfill gas bottle with additional $\mathrm{CO}_{2}$ was not cleaned, but fuelled directly into the SOFC. Interestingly, the performance did not change and also the degradation rate - even though followed only for a rather short period of ca. $24 \mathrm{~h}$ - was also very small. Obviously, the used landfill gas did not contained critical contaminants. While in a biogas SOFC system a cleaning certainly was recommended, this initial test shows that the needed purification might not be too demanding for such a type of landfill gas.

\section{Conclusion}

In the current work, the poisoning of reactions in the system biogas in combination with steam and dry reforming was investigated directly in a solid oxide fuel cell. The catalytic reforming reactions are severely poisoned at $\mathrm{H}_{2} \mathrm{~S}$ concentrations around $2-40 \mathrm{ppm}$, while the water gas shift reaction is less sensitive. Comparing dry and steam reforming, there seems to be a difference at the lower $\mathrm{H}_{2} \mathrm{~S}$ concentrations, the dry reforming being less poisoned.

It was further demonstrated, that an SOFC can run on synthetically mixed biogas under steam reforming conditions and in the presence of a few ppm $\mathrm{H}_{2} \mathrm{~S}$ for as long as 3,000 h, however, with significant degradation rates. Increasing the operating temperature did not affect the degradation rate significantly. On the other hand, dry reforming conditions improved the durability in the presence of $\mathrm{H}_{2} \mathrm{~S}$ significantly in synthetically mixed biogas.

Initial durability tests in real landfill gas collected at a landfill unit and supplied with extra $\mathrm{CO}_{2}$ to allow for dry reforming showed very good performance and stability of performance, even when the cleaning unit was disconnected. These results are very promising regarding efficient electricity production using SOFC in combination with biogas from landfill units, which can contribute to future sustainable energy systems.

\section{Acknowledgment}

The authors are very grateful to Ulrik Lønkjær and Rasmus Olsen from Odense Renovation for providing real biogas from the landfill unit in Odense Renovation. We also thank Ole Hansen and Henrik Henriksen from DTU Energy for collecting the biogas and technical assistance. 


\section{References}

[1] http://www.ens.dk/undergrund-forsyning/vedvarende-energi/bioenergi/biogas, July 2016.

[2] Danish Energy Agency: Energy Statistics 2014, http:// www.ens.dk/en/info/facts-figures/energy-statisticsindicators-energy-efficiency/annual-energy-statistics, July 2016.

[3] H. Chum, A. Faaij, J. Moreira, G. Berndes, P. Dhamija, H. Dong, B. Gabrielle, A. Goss Eng, W. Lucht, M. Mapako, O. Masera Cerutti, T. McIntyre, T. Minowa, K. Pingoud, Bioenergy, in IPCC Special Report on Renewable Energy Sources and Climate Change Mitigation (Eds. O. Edenhofer, R. Pichs-Madruga, Y. Sokona, K. Seyboth, P. Matschoss, S. Kadner, T. Zwickel, P. Eickemeier, G. Hansen, S. Schlömer, C. von Stechow), Cambridge University Press, Cambridge, United Kingdom and New York, NY, USA, 2011.

[4] S. Torija, A. Castillo-Castillo, N. P. Brandon, Fuel Cells 2016, 16, 55.

[5] J. Van herle, Y. Membrez, O. Bucheli, J. Power Sources 2004, 127, 300.

[6] S. Frederic, http://www.biogas-renewable-energy.info/ biogas_composition.html, August 2016.

[7] E. Bocci, A. Di Carlo, S. J. McPhail, K. Gallucci, P. U. Foscolo, M. Moneti, M. Villarini, M. Carlini, Int. J. Hydrogen Energy 2014, 39, 21876.
[8] J. F. B. Rasmussen, A. Hagen, J. Power Source 2009, 191, 534.

[9] A. Hagen, J. F. B. Rasmussen, K. Thydén, J. Power Sources 2011, 196, 7271.

[10] J. F. B. Rasmussen, A. Hagen, Fuel Cells 2010, 10, 1135.

[11] A. Hagen, J. Electrochem. Soc. 2013, 160, F111.

[12] A. Hauch, A. Hagen, J. Hjelm, T. Ramos, J. Electrochem. Soc. 2014, 161, F734.

[13] A. Hauch, A. Hagen, J. Hjelm, T. Ramos, ECS Trans. Proc. SOFC XIII 2013, 57, 615.

[14] K. Sasaki, K. Haga, T. Yoshizumi, D. Minematsu, E. Yuki, R.-R. Liu, C. Uryu, T. Oshima, S. Taniguchi, Y. Shiratori, K. Ito, ECS Transactions 2011, 35, 2805.

[15] J. Staniforth, K. Kendall, J. Power Sources 1998, 71, 275.

[16] J. Staniforth, K. Kendall, J. Power Sources 2000, 86, 401.

[17] C. Guerra, A. Lanzini, P. Leone, M. Santarelli, D. Beretta, Int. J. Hydrogen Energy 2013, 38, 10559.

[18] A. Lanzini, P. Leone, C. Guerra, F. Smeacetto, N. P. Brandon, M. Santarelli, Chemical Engineering Journal 2013, 220, 254.

[19] G. B. Johnson, P. Hjalmarsson, K. Norrman, U. S. Ozkan, A. Hagen, Fuel Cells 2016, 16, 219.

[20] R. Barfod, A. Hagen, S. Ramousse, P. V. Hendriksen, M. Mogensen, Fuel Cells 2006, 6, 141.

[21] J. Rostrup Nielsen, Catalytic Steam Reforming, Springer Verlag, Berlin, Heidelberg, Germany, 1984.

[22] J. R. Rostrup-Nielsen, J. Catal. 1984, 85, 31. 